\title{
Nutritional attributes, bioactive components and overall acceptability of pineapple grown under different farming system
}

\section{Lokesh K Mishra}

Department of Basic Science and Humanities, College of Home Science, Central Agricultural University, Tura -794005 (Meghalaya) INDIA

E-mail: 1kmishra2005@gmail.com

Received: December 6, 2016; Revised received: June 24, 2017; Accepted: October 28, 2017

Abstract: Nutritional attributes, bioactive components and sensory qualities of pineapple (kew variety) grown under fertilizer based and traditional (organic by default) farming system were determined and compared in this study. The results revealed that organically grown (without adding any chemical inputs as per traditional practices) pineapple had significantly higher bioactive components (vitamin c and total soluble phenolics ranging from $23.19 \%$ to 24.04 $\%$ and $28.69 \mathrm{mg} / 100 \mathrm{~g} \mathrm{FW}$ to $29.54 \mathrm{mg} / 100 \mathrm{~g}$ fresh weight (FW) respectively for organically grown fruits and $19.84 \%$ to $20.01 \%$ and $21.32 \mathrm{mg} / 100 \mathrm{~g} \mathrm{FW}$ to $21.93 \mathrm{mg} / 100 \mathrm{~g} \mathrm{FW}$ respectively in conventionally grown in fruits). The study also reports that the organically grown pineapples had significantly higher overall acceptability (4.5 and 4.3 in 2013 and 2014 respectively) and popularity (4.26 and 4.32 in 2013 and 2014 respectively) as compared to the pineapples grown under conventional farming system using fertilizers ( 2.8 overall acceptability in 2013 and $2014 ; 2.96$ and 2.86 popularity in 2013 and 2014 respectively).

Keywords: Nutritional quality, Organic farming, Pineapple, Sensory qualities

\section{INTRODUCTION}

India is the sixth largest pineapple-producing country in the world contributing a share of $5.91 \%$ of the global output in 2013 (Apeda 2014) . Its north-eastern region (NER) plays a significant role in this by way of contributing more than half of the total production of $1571 \mathrm{MT}$ in 2013. In fact, six of the seven states of the region consistently feature in country's top ten pineapple-producing belts and almost most of these are grown organically (SFAC 2012). The state of Meghalaya in this region is regarded as "Pineapple Hub" with pineapple being the second most important fruit in terms of area in the state. This is evident from the fact that among the fruit crops, the maximum area is under pineapple (9.5 thousand ha) (Lyngdoh 2014). Health concerns and awareness related to environment in which the food is grown have led to a great increase in the demand for food which is grown organically using negligible chemical fertilizers and other chemical inputs.

In several parts of the country, particularly the states of North East India, the inherited traditional farming practices stress up on the utilization of bioresources by tribal farmers based on indigenous and traditional knowledge that helps in sustainable use and conservation of natural resources (Majumder et al. 2010). These farmers do not use chemical fertilizers or other chemical inputs for farming. Those systems and products that are organically produced but are not certified also represent a significant portion of production and are referred to as "non-certified organic agriculture or products."

The nutritional quality of food grown by organic and conventional methods is the subject of much controversy (Lairon 2011; Bourn and Prescott 2002; Williams 2000; Magkos et al. 2003). Pineapple is an important fruit crop which has a significant role in the economy of Meghalaya. Focus of most of the studies has mostly been to compare the organically and conventionally produced farm products on the marketing, agronomic aspects and the impact of organic farming on soil characteristics. (Ramesh et al. 2008; 2009). Studies comparing the nutritional qualities, sensory attributes of farm products particularly fruits grown using fertilizer and those grown without any chemical inputs are scarce. In recent times the North-East region of India has received greater attention as a potential region for promoting organic cultivation and farming practices. Research focussing on agronomic and marketing aspects of organic farming have been published earlier (Ramesh et al. 2008; 2009; Darnhofer et al. 2010), but comparing the nutritional content of organically and conventionally produced fruits is also important. These facts formed the basis for planning this research study to determine the nutritional, bioactive components and sensory attributes of the pineapple fruits grown under traditional farming system of Meghalaya (default organic by tradition) and pineapple 
grown under conventional fertilizer based system.

\section{MATERIALS AND METHODS}

Collection of sample: Freshly harvested pineapples (Kew variety) grown under conventional farming system and organic farming system were collected at moderate ripening stage (three-quarters of the shell colour yellow); from the farmers field. Samples were transported in paper cartons to the laboratory and kept refrigerated at $5-8^{\circ} \mathrm{C}$ prior to analyses which were completed over a five-day period. Three replicates each of the samples grown under two different farming systems were sampled for further analysis.. In each replicate five fruits were selected for all the analyses. The samples collected were grown under same environmental (warm, humid, sub-tropical) and soil conditions (Red sandy loam) but were cultivated under two different farming systems.

Physico-chemical analysis: Fruits samples collected were weighed using a top loading balance (SalterAND Model, Japan), the weight of the samples were determined and expressed in grams. Using a pineapple slicer, the flesh of the pineapples was scooped, passed through a juice extractor and the juice collected in a measuring cylinder to measure the volume $(\mathrm{ml})$. The percentage of juice content in the peeled fruit pulp was calculated using the following formula:

$$
6 \text { of jwice in fruit }=\frac{\text { weight of jures }}{\text { weight of pulp }} \times 100
$$

The juice was further analyzed for total soluble solids (TSS), $\mathrm{pH}$ and titratable acidity (TA). TSS was measured with a digital refractometer PR-10. The $\mathrm{pH}$ was measured at room temperature using Sartorius Professional Meter. Titratable acidity (TA) was determined by titrating $10 \mathrm{~mL}$ juice with $0.1 \mathrm{~N} \mathrm{NaOH}$ to $\mathrm{pH} 8.2$ with phenolphthalein as an indicator. The titratable acidity was expressed as a percentages of citric acid (mole equivalent $=0.064)$. Following formula was used to calculate the titratable acidity:

Percent acid $=(0.1 \times 0.064 . \mathrm{mL}$ of $0.1 \mathrm{~N} \mathrm{NaOH}$ used $)$ $\mathrm{x} 100 / \mathrm{mL}$ of sample taken

Sweetness Index (SI) was derived as the ratio of the total soluble solids content $\left({ }^{\circ}\right.$ Brix) to titratable acidity (\%) and astringency index (AI) was expressed as the ratio of titratable acidity (\%) to soluble solids content ( ${ }^{\circ}$ Brix) ( Beckles 2012).

Nutritional analysis: Uniformly sized fruit samples (1.5 kg fruit weight) were collected at M2 ripening stage (Three fourth of the shell color yellow) and washed thoroughly with tap water. The fruit samples were peeled and sliced into pieces of uniform size. These were allowed to dry under room temperature for three hours to remove excess moisture. For all the analysis except the moisture content the fruit samples in triplicate were dried in an air oven at $55^{\circ} \mathrm{C}$ for 36 hours and finely powdered with a pestle and mortar.
The powder was kept in a sealed polyethylene pouch and kept in refrigerator for further analysis. The determination of vitamin $\mathrm{C}$ was done in fresh fruits only. Total soluble sugars were determined according to the method of Yem and Willis (1954). Reducing sugars were estimated using alkaline-copper and arsenomolybdate as reagent in accordance with NelsonSomogyi's modified method (Marais et al., 1966). The moisture content was determined as per the method prescribed by AOAC (1990). 5.0 grams of samples were taken in pre-weighed crucible and placed in an air oven maintained at $105^{\circ} \mathrm{C}$ for $8 \mathrm{hr}$. The crucibles were transferred immediately to desiccators, cooled and weighed. All the analysis was done in triplicates. The moisture content $(\%)$ determined in the fruit sample was calculated as follows:

$$
\text { noisture }(06)=\frac{\text { losin waiht }(9)}{\text { wathoisula } 60} \times 100
$$

The mineral ash content in the fruit samples of was done according to the method of Association of Official Analytical Chemists (AOAC 1990). The Vitamin $\mathrm{C}$ content was determined in fresh fruit samples according to indophenol method. Total phenolic content of extract was determined using Folin-Ciocalteu's phenol reagent as adapted from Velioglu et al. (1998) with slight modifications. Three hundred microlitre of extract was mixed with $2.25 \mathrm{ml}$ of Folin- Ciocalteu's phenol reagent (1:10 dilution) and allowed to stand at room temperature for $5 \mathrm{~min}$. Then $2.25 \mathrm{ml}$ of sodium carbonate $(60 \mathrm{~g} / \mathrm{l})$ was added to the mixture. After 90 min at room temperature, absorbance was measured at $725 \mathrm{~nm}$. The total phenolic content of each sample was estimated by using the standard curve generated from gallic acid. All determinations were done in triplicate and the results were expressed as $\mathrm{mg}$ of gallic acid equivalents (GAE) / 100g of fresh weight of sample.

Sensory evaluation of Pineapple: Sensory evaluation (Lawless and Heymann 1998) test of the fresh pineapple fruit juice was conducted in such a way so as to create enough space between taste panels, so that they do not influence one another with conversation or facial expressions. The samples were coded with random letters. Then, the tasters were given an evaluation form. They were asked to taste one sample at a time, and record their responses. Adequate time (10-15 min) was given to the panellists between samples so that they can record their opinions.

In this test, a 10-members panel were selected to evaluate the quality of fresh pineapple juice. The untrained panellists were randomly assigned the samples blindly and were requested to express their feelings about the samples by scoring the following attributes: Appearance (colour), Flavour (sweetness versus tartness), Aroma (odour sensation), Texture (tenderness versus firmness) and Overall preference. The samples were evaluated using a five-point Hedonic scale: 1: 
Dislike extremely; 2: Dislike; 3: Neither like nor dislike; 4: Like; 5: Like extremely. Popularity of the pineapple cultivars among the taste panellists was estimated by averaging the scores of all sensory attributes.

Statistical analysis: Means, standard errors and standard deviations were calculated from replicates using MS-Excel. All data was subjected to a one- way ANOVA, and the means were compared using Tukey's test $(p \leq 0.05)$.

\section{RESULTS AND DISCUSSION}

Physico-chemical analysis: The data (Table 1) suggests that the fruit weight of the pineapple grown under conventional farming system was higher as compared to organically produced pineapple. This trend is visible in both the years of analysis. The maximum fruit weight recorded was 1499.56 grams in the fruit grown under conventional farming system and it was statistically significant over the fruit weight $(p \leq 0.05)$ of the pineapple grown organically. The significant higher fruit weight of the pineapples grown under conventional farming system may be attributed to the use of fertilizers have positive impact on vegetative growth and fruit size of pineapple plants. High $\mathrm{pH}$ of the soil and low " $\mathrm{N}$ " availability compared to conventional farming system under organic farming may be the reasons for lower fruit weight. Similar findings have been reported by Malezieux and Duane (2003) in pineapple and Roussos and Gasparatos (2009) in Apples.

Juice content of pineapple fruits grown under organic and conventional farming system is presented in (Table 1) indicates that the difference was nonsignificant between the pineapples grown under the two farming systems $(\mathrm{p} \leq 0.05)$.

$\mathrm{pH}$ influences the sample colour, aroma, flavor, oxidation, microbial and chemical stability directly. The results of the reveal that the $\mathrm{pH}$ of the pineapple fruit juice grown under organic farming ranged from 3.89 to 4.78 and 3.69 to 4.55 in 2013 and 2014 and those under conventional farming had $\mathrm{pH}$ in the range of 4.22 to 5.42 in 2013 and 3.45 to 4.56 in the year 2014. The difference between the $\mathrm{pH}$ of the fruit juice samples grown under organic and conventional farming system indicate a statistically non-significant difference ( $p \leq$ 0.05 ). Similar $\mathrm{pH}$ range has been reported in pineapple 'FLHORAN41' and 'Smooth Cayenne' by Brat et al.

Table 1. Physicochemical characteristics of pineapple (kew cultivar) grown under organic and conventional farming conditions in two consecutive years of investigation.

\begin{tabular}{lcccc}
\hline \multirow{2}{*}{ Parameters } & \multicolumn{2}{c}{$\mathbf{2 0 1 3}$} & \multicolumn{2}{c}{$\mathbf{2 0 1 4}$} \\
\cline { 2 - 5 } & Organic & Conventional & Organic & Conventional \\
\hline Weight of Fruit (In grams) & $1292.36^{\mathrm{a}}( \pm 65.17)$ & $1517.92^{\mathrm{b}}( \pm 42.73)$ & $1327.92^{\mathrm{a}}( \pm 54.24)$ & $1499.56^{\mathrm{b}}( \pm 49.12)$ \\
Juice Content (In \%) & $65.09^{\mathrm{a}}( \pm 2.43)$ & $68.34^{\mathrm{b}}( \pm 1.74)$ & $64.25^{\mathrm{a}}( \pm 3.17)$ & $68.51^{\mathrm{b}}( \pm 2.36)$ \\
Total Soluble Solids (In ${ }^{0}$ Brix) & $14.05^{\mathrm{a}}( \pm 1.05)$ & $12.35^{\mathrm{b}}( \pm 0.99)$ & $13.85^{\mathrm{a}}( \pm 0.93)$ & $12.41^{\mathrm{b}}( \pm 1.06)$ \\
$\mathrm{pH}$ & $4.36^{\mathrm{a}}( \pm 0.29)$ & $4.18^{\mathrm{a}}( \pm 0.23)$ & $4.99^{\mathrm{a}}( \pm 0.28)$ & $4.74^{\mathrm{a}}( \pm 0.35)$ \\
Titratable Acidity (\% acid as citric acid & $0.643^{\mathrm{a}}( \pm 0.03)$ & $0.663^{\mathrm{a}}( \pm 0.02)$ & $0.652^{\mathrm{a}}( \pm 0.02)$ & $0.662^{\mathrm{a}}( \pm 0.02)$ \\
equivalent) & $21.89^{\mathrm{a}}( \pm 1.92)$ & $18.78^{\mathrm{b}}( \pm 1.73)$ & $21.24^{\mathrm{a}}( \pm 1.12)$ & $18.79^{\mathrm{b}}( \pm 1.91)$ \\
Sweetness Index & $0.045^{\mathrm{a}}( \pm 0.0042)$ & $0.0054^{\mathrm{b}}( \pm 0.0045)$ & $0.047^{\mathrm{a}}( \pm 0.0026)$ & $0.053^{\mathrm{b}}( \pm 0.0059)$ \\
Astringency Index &
\end{tabular}

Data are the mean values ( \pm standard deviation) of organically and conventionally grown pineapple fruits. Values bearing different superscripts are significantly different $(\mathrm{p} \leq 0.05)$.

Table 2. Nutritional characteristics of pineapple (kew cultivar) grown under organic and conventional farming conditions in two consecutive years of investigation.

\begin{tabular}{lcccc}
\hline \multirow{2}{*}{ Parameters } & \multicolumn{2}{c}{$\mathbf{2 0 1 3}$} & \multicolumn{2}{c}{$\mathbf{2 0 1 4}$} \\
\cline { 2 - 5 } & Organic & Conventional & Organic & Conventional \\
\hline Moisture Content (In \%) & $83.08^{\mathrm{a}}( \pm 0.68)$ & $84.65^{\mathrm{b}}( \pm 0.86)$ & $83.31^{\mathrm{a}}( \pm 0.91)$ & $86.09^{\mathrm{b}}( \pm 0.74)$ \\
Total Soluble Sugar Content (In \%) & $12.79^{\mathrm{a}}( \pm 0.72)$ & $11.98^{\mathrm{b}}( \pm 0.49)$ & $13.02^{\mathrm{a}}( \pm 0.74)$ & $12.20^{\mathrm{b}}( \pm 0.45)$ \\
Reducing Sugar Content (In \%) & $4.56^{\mathrm{a}}( \pm 0.16)$ & $4.17^{\mathrm{b}}( \pm 0.06)$ & $4.55^{\mathrm{a}}( \pm 0.27)$ & $4.21^{\mathrm{b}}( \pm 0.17)$ \\
Mineral Ash Content (In \%) & $1.30^{\mathrm{a}}( \pm 0.12)$ & $1.43^{\mathrm{a}}( \pm 0.15)$ & $1.43^{\mathrm{a}}( \pm 0.10)$ & $1.41^{\mathrm{a}}( \pm 0.21)$ \\
\hline
\end{tabular}

Data are the mean values ( \pm standard deviation) of organically and conventionally grown pineapple fruits. Values bearing different superscripts are significantly different $(\mathrm{p} \leq 0.05)$.

Table 3. Bioactive content of pineapple (kew cultivar) grown under organic and conventional farming conditions in two consecutive years of investigation.

\begin{tabular}{lcccc}
\hline \multirow{2}{*}{ Parameters } & \multicolumn{2}{c}{$\mathbf{2 0 1 3}$} & \multicolumn{2}{c}{$\mathbf{2 0 1 4}$} \\
\cline { 2 - 5 } & Organic & Conventional & Organic & Conventional \\
\hline Vitamin C(mg/100g FW) & $23.19^{\mathrm{a}}( \pm 0.95)$ & $19.84^{\mathrm{b}}( \pm 0.71)$ & $24.04^{\mathrm{a}}( \pm 0.35)$ & $20.01^{\mathrm{b}}( \pm 1.08)$ \\
Total Polyphenol Content (In mg/g GAE FW) & $28.69^{\mathrm{a}}( \pm 1.77)$ & $21.32^{\mathrm{b}}( \pm 1.04)$ & $29.54^{\mathrm{a}}( \pm 1.35)$ & $21.93^{\mathrm{b}}( \pm 0.93)$ \\
\hline
\end{tabular}

Data are the mean values ( \pm standard deviation) of organically and conventionally grown pineapple fruits. Values bearing different superscripts are significantly different $(\mathrm{p} \leq 0.05)$. 
Table 4. Sensory attributes of pineapple (kew cultivar) grown under organic and conventional farming conditions in two consecutive years of investigation.

\begin{tabular}{lcccc}
\hline \multirow{2}{*}{ Parameters } & \multicolumn{2}{c}{$\mathbf{2 0 1 3}$} & & $\mathbf{2 0 1 4}$ \\
\cline { 2 - 5 } & Organic & Conventional & Organic & Conventional \\
\hline Appearance & $4.1^{\mathrm{a}}( \pm 0.56)$ & $3.3^{\mathrm{b}}( \pm 0.48)$ & $4.4^{\mathrm{a}}( \pm 0.51)$ & $3.0^{\mathrm{b}}( \pm 0.66)$ \\
Flavour & $4.5^{\mathrm{a}}( \pm 0.52)$ & $2.8^{\mathrm{b}}( \pm 0.78)$ & $4.3^{\mathrm{a}}( \pm 0.48)$ & $3.2^{\mathrm{b}}( \pm 0.63)$ \\
Aroma & $3.8^{\mathrm{a}}( \pm 0.78)$ & $2.8^{\mathrm{b}}( \pm 0.63)$ & $4.2^{\mathrm{a}}( \pm 0.78)$ & $2.7^{\mathrm{b}}( \pm 0.67)$ \\
Texture & $4.5^{\mathrm{a}}( \pm 0.52)$ & $3.0^{\mathrm{b}}( \pm 0.81)$ & $4.4^{\mathrm{a}}( \pm 0.69)$ & $\left.2.7^{\mathrm{b}} \pm 0.82\right)$ \\
Overall Acceptability & $4.5^{\mathrm{a}}( \pm 0.52)$ & $2.8^{\mathrm{b}}( \pm 0.78)$ & $4.3^{\mathrm{a}}( \pm 0.48)$ & $2.8^{\mathrm{b}}( \pm 0.63)$ \\
Popularity & $4.26^{\mathrm{a}}( \pm 0.25)$ & $2.96^{\mathrm{b}}( \pm 0.31)$ & $4.32^{\mathrm{a}}( \pm 0.32)$ & $2.86^{\mathrm{b}}( \pm 0.35)$ \\
\hline
\end{tabular}

Data are the mean values ( \pm standard deviation) of organically and conventionally grown pineapple fruits. Values bearing different superscripts are significantly different $(\mathrm{p} \leq 0.05)$.

(2004), 'Phulae' and 'Nanglae' cultivars by Kongsuwan et al. (2009) and 'Gold' cultivar by MonteroCalderon et al. (2010). The $\mathrm{pH}$ values observed in this study may have been affected by the maturity stage of the fruits used for analysis (M2 stage having three fourth of the shell color yellow). Recent studies have suggested that variations in the acidity of fleshy fruits are mainly due to the enhanced levels of organic acids such as malic and citric acids in mature ripened fruits (Etienne et al. 2013).

Titratable acidity (TA): which measures the concentration of citric acid (principle acid in pineapple) had no significant differences among the fruits grown under two farming system $(p \leq 0.05)$. Total soluble solids (TSS) indicates sugar content (sucrose, glucose and fructose) and is measured by capacity of solutions to bend or refract a light beam in proportion to the concentration of soluble solids and the refraction is used as a measure of the solution density (Potter and Hotchkiss 1998). Data presented (Table 1) indicate that the Total soluble solid (TSS) ranged from 12.59 to 15.43 and 12.43 to 15.11 in 2013 and 2014 respectively in fruit samples grown under organic farming. The fruits grown under conventional farming recorded a TSS in the range of 10.7 to 13.88 in 2013 and 10.14 to 13.87 in the year 2014. The TSS recorded in fruits grown under organic farming condition was significantly higher as compared to the fruits grown under conventional farming system. Total soluble solid (TSS) is used as an indicator of fruit maturity and quality and for pineapple it ranged between $11.5-14.7^{0}$ Brix in findings reported by (Marrero and Kader, 2006). Earlier studies conducted by Spironello et al. (2004) indicate that increasing the levels of nitrogen which is used as fertiliser leads to decrease in the Brix value and reduces sugar content of the juice. This may be the reason for lower TSS values in the fruit samples grown under conventional farming system.

Sweetness Index (SI) is calculated as the ratio of the total soluble solids content $\left({ }^{\circ} \mathrm{Brix}\right)$ to titratable acidity $(\%)$ whereas astringency Index (AI) is estimated as the ratio of titratable acidity (\%) to soluble solids content ( ${ }^{\circ}$ Brix). The flavour and quality of food are not contributed by sugar or acid content alone but the interaction between them. Hence, sugar-acid ratio is com- monly used for describing the flavour of fruits rather than sugar or acid alone (Potter and Hotchkiss 1998; Sadler and Murphy 2010). The results of the sweetness index and astringency index for the fruit samples grown under organic and conventional farming system indicate non-significant differences $(p \leq 0.05)$ (Table 1).

Nutritional analysis of pineapples grown under organic and conventional farming system: A careful perusal of the data pertaining to nutritional analysis of the pineapple fruit (Table 2) indicates that the difference between moisture content in the fruits grown under two farming systems viz., organic and conventional was statistically non-significant. Similar findings with respect to moisture content have been reported in other pineapple cultivars. For example (Inyang and Agbo 1995) reported that moisture content in 'Queen' cultivar ranged from 69.0 to 89.5 per cent depending on the ripening period. Dhar et al. (2008) reported that moisture content in the 'Giant Kew' cultivar ranged from 81.21 to 84.36 percent.

Sugar content is a crucial factor for determining the quality and sensory acceptability of fruits and vegetables. Data for the Total soluble sugar content in the mature fruit samples grown under the organic and conventional farming clearly indicates that the organic farming system had a positive impact on the total sugar content as compared to the conventional farming system but the increase was statistically non-significant ( $p$ $\leq 0.05$ ) (Table 2 ). The range of total soluble sugar obtained in this study conforms with the findings of Deka et al. (2005) who have reported that total soluble sugar in 'Kew' variety of pineapple ranges from 6.49 to 12.74 per cent.

The reducing sugars are very much instrumental in determining the overall taste and flavour of the pineapple and most other fruits and vegetables. The reducing sugars commonly found in pineapple are glucose and fructose. The data concerned with the impact of organic and conventional farming systems on reducing sugar content suggests that reducing sugar content in organically farmed pineapple ranged from 4.32 to 4.81 percent in 2013 and 4.12 to 4.94 percent in 2014. In comparison, the conventionally produced pineapples had reducing sugar in the range of 4.09 to 4.31 per cent 
and 4.01 to 4.52 per cent in 2013 and 2014 respectively. The difference between the reducing sugar content in the pineapple grown under organic farming system was significantly higher in 2013 but had nonsignificant differences were observed in 2014. Earlier studies suggest that lowering nitrogen availability leads to about 5-17\% increase in soluble sugar content in tomato (Benard et al. 2009). Carbohydrates compete with protein synthesis for photosynthates, the products of photosynthesis. Higher levels of nitrogen lead to a higher protein-carbohydrate ratio and, therefore a decline in carbohydrate content especially the reducing sugars (Salunke and Desai 1998). The reducing sugar content found in pineapple fruits in both the farming systems in the present investigation are in concurrence with the findings of Dhar et al. (2008).

The Mineral Ash content in organically farmed pineapple fruits ranged from 1.10 to 1.45 percent in 2013 and 1.31 to 1.67 per cent in 2014. As compared to organic farming the pineapple fruits grown under conventional farming had higher but non-significant $(p \leq 0.05)$ differences. In these samples, the mineral ash content ranged from 1.16 to 1.91 percent in 2013 and 1.12 to 1.71 per cent in 2014. Careful perusal of the data pertaining to the Vitamin $\mathrm{C}$ content in the pineapple fruits (Table 3) indicates that the vitamin $\mathrm{C}$ content in the organically farmed pineapple ranged from 21.19 to $24.56 \mathrm{mg} / 100 \mathrm{~g} \mathrm{FW}$ in 2013 and 23.19 to 24.53 $\mathrm{mg} / 100 \mathrm{mg} \mathrm{FW}$ in 2014. In comparison to the pineapple fruits grown under conventional farming system, the vitamin c content was significantly higher in the fruits obtained from organic farming. In the study by Kongsuwan et al. (2009), vitamin C content was 188.8 and $64.5 \mu \mathrm{g} / \mathrm{g}$ in 'Phulae' and 'Nanglae' pineapple cultivars respectively. Another study also reported that vitamin C content in 'Gold' pineapple ranged from 305 $-333 \mu \mathrm{g} / \mathrm{g}$ (Montero-Calderon et al. 2010). Higher vitamin C content ( $28 \%$ higher on average) in organic vegetables as well as higher dry matter content $(23 \%$ higher) despite the lower yield (24\% lower) has been reported by earlier studies (Williams et al. 2000). Kumpulainen. (2001) reported that concentration of vitamin $\mathrm{C}$ was either equal (about $50 \%$ of the studies) or higher (also about $50 \%$ of the studies) in organic potatoes. One mechanism suggested for reduced vitamin $\mathrm{C}$ content in conventionally produced products as compared to those grown under organic farming is that increasing availability of plant available nitrogen in conventional farming reduces the accumulation of defense-related secondary metabolites and vitamin $\mathrm{C}$ (Brandt et al., 2011).

The total phenolics content assay in the fruit samples is a measure of the bioactive compound present in pineapples as affected by the two different farming systems. These assays are electron transfer based assays using Folin-Ciocalteu's phenol reagent to measure the reducing capacity of sample. Although the exact chemical nature of this intense yellow reagent is undefined, it is suggested to contain heteropolyphosphotungstates-molybdates and can be reduced by many compounds either phenolics or non-phenolics such as vitamin $\mathrm{C}$ via electron-transfer mechanism (Huang and Prior 2005). The data related to the total phenolic content in the pineapple fruits grown under organic and conventional farming system (Table 3 ) indicates that the total phenolic content in the organically farmed fruits was significantly higher $(p \leq 0.05)$ as compared to the fruits obtained from conventional farming system. The total phenolic content in the organically produced pineapples ranged from 25.65 to $31.17 \mathrm{mg}$ GAE/100g FW in 2013 and 26.61 to $31.56 \mathrm{mg}$ GAE/100g FW in 2014. The fruits produced under the conventional farming system had the total phenolic content in the range of 20.09 to $22.65 \mathrm{mg} \mathrm{GAE} / 100 \mathrm{~g}$ FW in 2013 and 20.76 to $23.16 \mathrm{mg} \mathrm{GAE} / 100 \mathrm{~g} \mathrm{FW}$ in 2014. Studies carried out by other researchers have indicated that organically grown kiwifruits (Actinidia deliciosa) were $15 \%$ higher in total phenolics (Amodio et al. 2007) as compared to conventionally grown kiwi fruits, and in organically versus conventionally grown sweet pepper (Capsicum annuиm L.), phenolics were $20-25 \%$ higher depending on the degree of ripening (Amor del 2007). Caris-Veyrat et al. (2004) found that tomatoes grown organically had higher phenolics on a fresh weight basis, but when the data were expressed on a dry weight basis, no differences in individual phenolic levels were detectable. Thus, the higher moisture content of conventionally grown food likely provides not only greater weight, that is, higher yields (tonnage) but also the possibility of nutrient dilution relative to drier organically grown crops. Zhao et al. (2006) in their review of organic versus conventional production enhancement of antioxidants, phenolics, and other phytochemicals stated that "evidence seems to favour enhancement by organic production systems".

Sensory evaluation of pineapples grown under organic and conventional farming systems: The results pertaining to sensory properties of pineapple (Table 4) show that pineapples grown under organic farming were preferred more in terms of appearance, flavour, aroma, texture and overall acceptability in both the years of the investigation. One of the possible reasons for better acceptability of the organically grown pineapple fruits may be higher sweetness index of these fruits recorded in both the years of experimentation which contributes greatly to the flavour and taste of fruits. Since sweetness index is a ratio between the titratable acidity and total soluble solids it may be concluded that interaction between these two parameters have a role in determining the flavour of the fruits. Similar reasoning to explain the impact of sweetness index on flavour has been advocated by Potter and Hotchkiss (1998) and Sadler and Murphy (2010). Earlier studies reported by Weibel et al. (2000) and Reg- 
anold et al. (2001) suggests that organic apples had significantly firmer flesh that conventionally grown apples. They also found organic apples had better taste. They also found the ratio of soluble solids (sugar) content to acidity (tartness), an indication of sweetness, to be most often highest in organic fruit.

\section{Conclusion}

The results of the study conclude that traditionally grown pineapples without any chemical inputs had significantly higher bioactive components and sensory attributes as compared to the pine apples grown conventionally. It may also be concluded that pineapple production under the conventional fertilizer based system was higher as compared to the organic farming systems as deduced from the fruit weight.

\section{ACKNOWLEDGEMENTS}

The "Intra-mural Research Grant" received from the Directorate of Research, Central Agricultural University, Imphal, Manipur, India for undertaking this research project is immensely acknowledged.

\section{REFERENCES}

Amodio, M.L., Colelli, G., Hasey, J.K. and Kader A. A. A. (2007). Comparative study of the composition and postharvest performance of organically and conventionally grown kiwifruits. J. Sci. Food Agric, 87:1228-1236.

Amor del, F. M. (2007). Yield and fruit quality response of sweet pepper to organic and mineral fertilization. Ren Agric. Food Syst, 22: 233-238.

APEDA (Agricultural and processed food products export development agency) Newsletter (2014). http:// agriexchange.apeda.gov.in/ (Accessed on September 8 2016).

Association of Official Analytical Chemists. (1990). Official methods of analysis of the AOAC. 15th Ed. Arlington, Va.

Beckles, D.M. (2012). Factors affecting the postharvest soluble solids and sugar content of tomato (Solanum lycopersicum L.) fruit. Postharvest Biol Technol, 63:129140.

Benard, C., Gautier, H., Bourgaud, F., Grasselly, D., Navez, B., Caris-Veyrat, C., Weiss M. and Genard, M. (2009). Effects of low nitrogen supply on tomato (Solanum lycopersicum) fruit yield and quality with special emphasis on sugars, acids, ascorbate, carotenoids, and phenolic compounds. J. Agric Food Chem, 57(10:1124123.

Bourn, D. and Prescott, J. (2002). A comparison of the nutritional value, sensory qualities, and food safety of organically and conventionally produced foods. Crit Rev Food Sci Nutr, 42 (1):1-34.

Brandt, K., Leifert, C., Sanderson, R. and Seal, C. J. (2011). Agroecosystem management and nutritional quality of plant foods: the case of organic fruits and vegetables. Crit Rev Plant Sci, 30(1-2):177-197.

Brat, P., Thi-Hoang, L.N., Soler, A., Reynes, M. and Brillouet, J.M. (2004). Physicochemical characterization of a new pineapple hybrid (FLHORAN41 Cv.). J. Agric
Food Chem, 52 (20): 6170-6177.

Caris-Veyrat, C., Amiot, M.J., Tyssandier, V., Grasselly, D., Buret, M., Mikolajczak, M., Guilland, J.C., BouteloupDemange, C. and Borel, P. (1995). Influence of organic versus conventional agricultural practices on the antioxidant micronutrient content of tomatoes and derived puree; consequences on antioxidant plasma status in humans. J. Agric Food Chem, 52: 6503-6509.

Darnhofer, I., Lindenthal, T., Bartel-Kratochvil, R. and Zollitsch, W. (2010). Conventionalisation of organic farming practices: from structural criteria towards an assessment based on organic principles. A Review. Agron for Sus Dev, 30(1): 67-81.

Deka, B.C., Saikia, J. and Sharma, S. (2005). Standardization of maturity indices of "Kew" pineapple. Acta Hortic, 3, 682: 2215-2220.

Dhar, M., Rahman, S.M. and Sayem, S.M. (2008). Maturity and Postharvest Study of Pineapple with quality and shelf life under red soil. Int J Sustain Crop Prod, 3(2): 69-75.

Etienne, A., Genard, M., Lobit, P., Mbeguie-A- Mbeguie, D. and Bugaud, C. (2013). What controls fleshy fruit acidity? A review of malate and citrate accumulation in fruit cells. J. Exp Bot, 64(6): 1451-1469.

Huang, D., Ou, B., and Prior, R. L. (2005). The chemistry behind antioxidant capacity assays. J. Agric Food Chem, 53(6), 1841-1856.

Inyang, U.E. and Agbo, A.U. (1995). Effect of hot ash treatment of mango fruits on the physicochemical changes during ripening. Trop. Sci, 35: 259-262.

Kongsuwan, A., Suthiluk, P., Theppakorn, T., Srilaong, V. and Setha, S. (2009). Bioactive compounds and antioxidant capacities of phulae and nanglae pineapple. Asian J. of Food Agro-Ind, 2 (S): 44-50.

Kumpulainen, J. T. (2001). Nutritional and toxicological quality comparisons between organic and conventionally grown foodstuffs. In Dalia Greidinger Symposium (The International Fertilizer Society), Lisbon 4-6.3. 2001. pt.

Lairon, D. (2011). Nutritional quality and safety of organic food. In Sustainable Agriculture Volume 2 (pp. 99-110). Springer Netherlands.

Lawless, H.T. and Heymann, H. (1998). Sensory evaluation of food: Principles and practices. Newyork: Chapmann and Hall. pp 361-372.Magkos

Lyngdoh, S. (2014). Strawberry cultivation: Horticultural Revolution in Meghalaya with reference to Sohliya and Mawpran Villages. Horticulture, 1(2): 3.

Majumder, M., Shukla, A. and Arunachalam, A. (2010). Agricultural practices in Northeast India and options for sustainable management. In Book: Biodiversity, Biofuels, Agroforestry and Conservation Agriculture, Volume 5, Sust Agric Rev, pp 287-315.

Malezieux, E. and Bartholomew, D. P. (2003). Plant nutrition. The pineapple: botany, production and uses, 143165.

Marais, J.P., De Wit, J.L. and Quicke, G.V. (1966). A critical examination of the Nelson-Somogyi method for the determination of reducing sugars. Anal Biochem, 15 (3):373-381

Marrero, A. and Kader, A. A. (2006). Optimal temperature and modified atmosphere for keeping quality of freshcut pineapples. Postharvest Biol and Technol, 39(2): 
163-168.

Montero-Calderon, M., Rojas-Grau, M.A. and MartinBelloso, O. (2010). Mechanical and chemical properties of Gold cultivar pineapple flesh (Ananas comosus). Eur Food Res Technol, 230 (4): 675-686.

Potter, N.N. and Hotchkiss, J.H. (1998). Food science. (5th ed.). Gaithersburg: Aspen Publishers.

Ramesh, P., Panwar, N.R., Singh, A.B. and Ramana, S. (2008). Effect of organic manures on productivity, soil fertility and economics of soybean-durum wheat cropping system under organic farming in vertisols. Ind $J$. Aric. Sci, 2008, 78: 1033-1037.

Ramesh, P., Panwar, N.R., Singh, A.B., Ramana, S. and Subba Rao, A. (2009). Impact of organic manure combinations on the productivity and soil quality in different cropping systems in central India. J. Plant Nutr Soil Sci, 172: 577-585

Reganold, J.P., Glover, J.D., Andrews, P.K. and Hinman, H.R. (2001). Sustainability of three apple production systems. Nature Magazine, 410. pp. 926-930.

Roussos, P.A. and Gasparatos, D. (2009). Apple tree growth and overall fruit quality under organic and conventional orchard management. Sci. Hortic, 123: 247-252.

Sadler, G.D. and Murphy, P.A. (2010). Chemical properties and characteristics of foods: $\mathrm{pH}$ and titratable Acidity. In S.S. Nielsen (Ed.), Food analysis (pp. 219-238). (5 ed.). New York: Springer.

Salunke D.K. and Desai, B.B. (1998). Effects of agricultural practices, handling, processing, and storage on vegeta- bles. In Karmas E., Harris R. S., Nutritional Evaluation of food processing. AVI, New York. pp. 23-72.

Spironello, A., Quaggio, J. A., Teixeira, L. A. J., Furlani, P. R. and Sigrist, J. M. M. (2004). Pineapple yield and fruit quality effected by NPK fertilization in a tropical soil. Revista Brasileira de Fruticultura, 26(1): 155-159.

Value chain analysis of select crops in North Eastern States (2012). http://sfacindia.com/PDFs/SFAC_Value-Chain -Analysis.pdf (Accessed September 8 2016).

Velioglu, Y.S., Mazza, G., Gao, L. and Oomah, B.D. (1998). Antioxidant activity and total phenolics in selected fruits, vegetables, and grain products. J. Agric Food Chem, 46 (9): 4113-4117.

Weibel, F.P., Bickel, R., Leuthold, S. and Alfoldi, T. (2000). Are organically grown apples tastier and healthier? A comparative field study using conventional and alternative methods to measure fruit quality. Acta Hortic, 517. pp. 417- 426 .

Williams, C.M., Bridges, O., Bridges, J.W., Pennington, H. and Tinker, P.B. (ed.). (2000). Shades of green- a review of UK farming systems. Royal Agricultural Society of England. pp.73-100.

Yem, E.W. and Willis, A.J. (1954). The estimation of carbohydrates in plant extracts by anthrone. Biochem.J, 57 (3): 508-514.

Zhao, X., Carey, E.E., Wang, W. and Rajashekar, C.B. (2006). Does organic production enhance phytochemical content of fruit and vegetables? Current knowledge and prospects for research. Hort Technol, 16: 449-456. 